\title{
EUでの研究論文のオープンアクセス化促進のための試験事業に ついて
}

\section{An European Pilot Initiative on Open Access to Peer Reviewed Research Articles}

\author{
国沢 隆
}

Takashi KUNISAWA

東京理科大学理工学部

Science University of Tokyo

干278-8510 千葉県野田市山崎 2641

E-mail: kunisawa@rs.noda.tus.ac.jp
研究論文のオープンアクセス化に向けて の具体的方策が実現化してきている.すで に本誌2月号で報告したように[1]、米国の National Institutes of Health (NIH) の資金 によって得られた研究成果を査読付き論文と して発表する場合には、研究者は論文が公 表されてから 1 年以内に最終原稿電子版を NIHのレポジトリーPubMed/Centralに送付す ることが義務付けられた[2]. 同様のオープン アクセス化が西欧で8月から試験的に導入さ れることになった $[3]$.このEUでの仕組みを NIHのそれと比較するとともに、日本の研究 者が研究成果の発表に際して直面している 問題点を報告する.

西欧ではFP7と呼ばれる7つの研究領域を 支援するプログラムが2007年から2013年まで 走っている. EU委員会はFP7から補助金を 得た研究者を対象として、研究論文のオー プンアクセス化のための試験事業を今年の8 月から立ち上げた. FP7の中で、このオープ ンアクセス化のための補助金を得た研究者 には次の2点を要求している.
1. 研究成果を査読付き論文として学術誌に 発表する場合には誰もが読めるように才 一プンアクセスとする、もしくは著者の最 終原稿をオンラインレポジリーに送付す る.

2. 送付期限は論文の発表から6か月（健康、 エネルギー、環境、情報通信技術の一 部、研究基盤などの5つの領域)もしくは 12 加 (社会人間科学、社会における科 学の $2 つ の$ 領域) とする.

この試験事業にはFP7の約20\%の資金が投 入され、FP7が終了するまで続く.

このように西欧のオープンアクセス化の対 象は、NIHの医学・生物学分野と比べて、広 い.また、論文の送付先・公開元は、NIHのよ うに機関レポジトリーばかりではなく、商業雑 誌のオープンアクセスのオプションを選択し てもよい.このため、オープンアクセスによっ て著者の最終原稿版だけでなく出版社の手 の入った雑誌公開版も利用可能となる. 
NIHや今回のECの決定により、オープン アクセスの動向はさらに強まるものと考えられ る. 実際に、公開費用の著者負担を原則と する雑誌が増えていて、研究者が論文を雑 誌に投稿した段階で数十万円が必要な雑誌 もある.このため、著者のまわりでは、研究対 象から考えてベストな雑誌への投稿を経済 的理由からあきらめざるをえないことが起こっ ている. 本誌2月号で提案したように[1]、我 が国でも、予算申請時にオープンアクセス化 のための予算を認める措置が緊急に採られ るべきである. また、同時に、論文の送付先・ 公開元となる機関レポジリーの整備が、NIH のように一括管理とするのか国立情報学研
究所(NII)が進めているような各大学図書館 を結ぶ分散型[4]にするのかは別にして、必 要である.

[1] 国沢隆：NIHのPublic Access方針につ いて：查読論文の国際的なGenBank化一 向けて、情報知識学会誌、Vol. 18, No. 1, p. 58-61, 2008

[2] http://publicaccess.nih.gov/ (2008/10/12 参照)

[3] http://ec.europa.eu/research/sciencesociety/index.cfm?fuseaction=public.topic\&i $\mathrm{d}=1680(2008 / 10 / 12$ 参照 $)$

[4] http://www.nii.ac.jp/irp/ 